3 Klussmann JP, Weissenborn SJ, Wieland U, et al. Human papillomaviruspositive tonsillar carcinomas: a different tumor entity? Med Microbiol Immunol (Berl) 2003;192:129-32

4 El-Mofty SK, Lu DW. Prevalence of human papillomavirus type 16 DNA in squamous cell carcinoma of the palatine tonsil, and not the oral cavity, in young patients: a distinct clinicopathologic and molecular disease entity. Am J Surg Pathol 2003;27:1463-70.

5 Devaraj K, Gillison ML, Wu TC. Development of HPV vaccines for HPVassociated head and neck squamous cell carcinoma. Crit Rev Oral Biol Med 2003:14:345-62.

6 Cubie HA, Seagar AL, McGoogan E, et al. Rapid real time PCR to distinguish between high risk human papillomavirus types 16 and 18. Mol Pathol $2001 ; 54: 24-9$.

7 de Roda Husman AM, Walboomers JM, van den Brule AJ, et al. The use of general primers GP5 and GP6 elongated at their 3 ends with adjacent highly conserved sequences improves human papillomavirus detection by PCR. J Gen Virol 1995;76:1057-62
8 Gravitt PE, Peyton CL, Alessi TQ, et al. Improved amplification of genital human papillomaviruses. J Clin Microbiol 2000;38:357-61.

9 Gravitt PE, Peyton CL, Apple RJ, et al. Genotyping of 27 human papillomavirus types by using LI consensus PCR products by a single-hybridization, reverse line blot detection method. J Clin Microbiol 1998;36:3020-7.

10 Maitland NJ, Cox MF, Lynas $C$, et al. Detection of human papillomavirus DNA in biopsies of human oral tissue. Br J Cancer 1987;56:245-50.

11 Ritchie JM, Smith EM, Summersgill KF, et al. Human papillomavirus infection as a prognostic factor in carcinomas of the oral cavity and oropharynx. Int J Cancer 2003; 104:336-44.

12 Lindel K, Beer KT, Laissue J, et al. Human papillomavirus positive squamous cell carcinoma of the oropharynx: a radiosensitive subgroup of head and neck carcinoma. Cancer 2001;92:805-13.

13 Hoffmann M, Gorogh T, Gottschlich S, et al. Human papillomaviruses in head and neck cancer: 8 year-survival-analysis of 73 patients. Cancer Lett 2005;218:199-206.

14 McKaig RG, Baric RS, Olshan AF. Human papillomavirus and head and neck cancer: epidemiology and molecular biology. Head Neck 1998;20:250-65.

\title{
Copper:caeruloplasmin ratio
}

\section{Patrick J Twomey, Adie Vilioen, Ivan M House, Timothy M Reynolds, Anthony S Wierzbicki}

Investigation of copper status can be a diagnostic challenge. The non-caeruloplasmin-bound copper (NCC) has deficiencies; accordingly, the copper:caeruloplasmin ratio has been suggested as an alternative index of copper status. A reference interval for this index was derived. In addition to making the interpretation of copper easier, the copper:caeruloplasmin ratio should also enable adjustment for relatively high caeruloplasmin concentrations without recourse to producing gender- and age-derived intervals. The copper:caeruloplasmin ratio has weaknesses similar to those identified for NCC in that immunological methods used for caeruloplasmin can cross react with apocaeruloplasmin and there is no standardised method for caeruloplasmin. Caeruloplasmin assays also have uncertainty from precision, bias and specificity and, accordingly, method-related differences may have a large effect on the copper:caeruloplasmin ratio in a manner similar to the NCC.

C opper studies are performed to identify copper deficiency or excess. Wilson's disease (primary copper excess), an autosomal recessive condition, ${ }^{1}$ results in copper deposition in the hepatic parenchymal cells, brain, iris and kidney. Its diagnosis can be a challenge. ${ }^{2}$ Secondary copper excess is rare in the developed world. Childhood primary copper deficiency has a poor prognosis and is often caused by an inherited defect in copper absorption (Menke's disease). ${ }^{3}$ Adult primary copper deficiency can cause a neurological condition similar to the extrapyramidal signs of Wilson's disease. ${ }^{4}$ Secondary copper deficiency is possible in patients receiving long-term enteral nutrition ${ }^{5}$ and with overuse of zinc supplementation. ${ }^{6}$ Copper studies are often requested to diagnose copper deficiency and to prevent neurological deterioration with supplementation.

The vast majority of copper in serum is bound to caeruloplasmin. ${ }^{7}$ Laboratories often do not take age and gender into account when reporting serum copper and caeruloplasmin reference intervals. ${ }^{8}$ Furthermore, caeruloplasmin has 6-8 copper atoms per molecule, with the majority being tightly bound. ${ }^{10}$ Heterogeneity in the number of copper atoms per caeruloplasmin molecule is possible, so any formula assuming six copper atoms per molecule may be valid only in certain situations.

Caeruloplasmin largely determines the copper concentration, ${ }^{11}{ }^{12}$ and plays a critical role in the interpretation of copper results. Some patients with Wilson's disease have copper and caeruloplasmin within their respective reference intervals, ${ }^{19}$ usually with copper being in excess of the caeruloplasmin concentration. Furthermore, about $2 \%$ of the population are heterozygous for P-type ATPase mutations, ${ }^{1}$ and often have caeruloplasmin results around the lower reference interval. Non-caeruloplasmin-bound copper (NCC) has been advocated as a superior diagnostic tool for Wilson's disease ${ }^{11}$ to try to overcome such issues. There are problems associated with the current use of the NCC; in particular, it produces physiologically impossible negative results in a significant number of patients. $^{12}$ To be effective in distinguishing patients with Wilson's disease from normal patients, the NCC may be expressed as a percentage of total copper. Furthermore, any index for the study of copper status should ideally have the potential to be used in the investigation of excess and deficiency copper states. Accordingly, new indices have been proposed, such as copper corrected for caeruloplasmin ${ }^{13}$ and the copper:caeruloplasmin ratio. ${ }^{14}$ The first study included only normal patients, whereas the second included patients with Wilson's disease who predominantly presented with neurological symptoms. We derived our own reference interval for this index.

Using the copper and caeruloplasmin data for 338 patients without Wilson's disease or copper deficiency, ${ }^{12}$ we calculated the copper:caeruloplasmin ratio ([copper] $\times 0.132 /$ [caeruloplasmin]) where copper is in $\mu \mathrm{mol} / \mathrm{l}$ and caeruloplasmin is in $\mathrm{g} / \mathrm{L}$.

Mean, median, SD and 2.5th and 97.5th centiles by both parametric and non-parametric methods for the copper:caeruloplasmin ratio were derived from measurements of copper (Varian Spectra 20) and caeruloplasmin (Tinaquant Kit; Hitachi 912; Roche, Welwyn, Hertfordshire, UK) assays. The copper:caeruloplasmin ratio ranged from 3.9 to $12.97 \mu \mathrm{mol} / \mathrm{g}$, with the mean and median being 6.81 and $6.83 \mu \mathrm{mol} / \mathrm{g}$, respectively. The SD was $0.87 \mu \mathrm{mol} / \mathrm{g}$ and, accordingly, the parametric reference interval was $5.08-8.55 \mu \mathrm{mol} / \mathrm{g}$ and the non-parametric 2.5 th

Abbreviation: NCC, non-caeruloplasmin-bound copper 
Take-home messages

- Investigation of copper status can be a diagnostic challenge.

- The non-caeruloplasmin-bound copper has deficiencies.

- The copper:caeruloplasmin ratio should produce values that are independent of gender and age.

- The copper:caeruloplasmin ratio, unlike non-caeruloplasin-bound copper, does not suffer from negative values; however, the other deficiencies of non-caeruloplasminbound copper also apply to the copper: caeruloplasmin ratio.

and 97.5th reference intervals using MS Excel were 5.05$8.09 \mu \mathrm{mol} / \mathrm{g}$. Analysing copper by Varian SpectrAA220G and caeruloplasmin by the Beckman-Coulter Array (High Wycombe, Buckinghamshire, UK), Beetham ${ }^{14}$ derived a ratio range of $4.0-8.5 \mu \mathrm{mol} / \mathrm{g}$. The difference at the upper end between the ranges may be due to either different analytical methods or the greater numbers in our study ( 338 vs 47 patient samples). After removing four outliers, Beetham's range was $5.2-7.3 \mu \mathrm{mol} / \mathrm{g}$, ${ }^{14}$ which is closer to our parametric and nonparametric reference intervals (5.08-8.55 and 5.05-8.09 $\mu \mathrm{mol} / \mathrm{g}$, respectively). As our reference intervals were 10-25 $\mu \mathrm{mol} / \mathrm{l}$ and 200-500 mg/l for copper and caeruloplasmin, respectively, the mean copper:caeruloplasmin ratio should theoretically be $6.6 \mu \mathrm{mol} / \mathrm{g}$, which is similar to both the study mean of $6.81 \mu \mathrm{mol} / \mathrm{g}$ and the theoretical mean of $6.7 \mu \mathrm{mol} / \mathrm{g}$ in Beetham's study. As stated by Beetham, this serves as a useful internal quality control check, providing an independent verification of caeruloplasmin calibration.

Beetham investigated seven patients with confirmed Wilson's disease and found a copper:caeruloplasmin ratio range of $9.0-44.0 \mu \mathrm{mol} / \mathrm{g}$; all these results would be above the upper reference limit using our methods. However, $0.3 \%$ (4/338) values exceeded $9.0 \mu \mathrm{mol} / \mathrm{g}$ in our population. Such patients may be normal or may be heterozygous for P-type ATPase mutations. ${ }^{1}$ The positive and negative predictive values of the copper:caeruloplasmin ratio would be acceptable at $63.6 \%$ and $100 \%$, respectively. Use of the parametric upper reference limit produces the same predictive values as above, whereas the nonparametric reference interval would have a positive predictive value of $46.7 \%$ while retaining a $100 \%$ negative predictive value, which is of the utmost importance in screening.

The copper:caeruloplasmin ratio is not just a way of making the interpretation of copper easier. It should enable adjustment for relatively high caeruloplasmin concentrations without recourse to producing gender- and age-derived intervals. ${ }^{89}$ The copper:caeruloplasmin ratio has weaknesses similar to those identified for $\mathrm{NCC}^{12}$ in that immunological methods used for caeruloplasmin can cross react with apocaeruloplasmin and there is no standardised method for caeruloplasmin.? Caeruloplasmin assays also have uncertainty from precision, bias and specificity ${ }^{15}$ and, accordingly, method-related differences may have a large effect on the copper:caeruloplasmin ratio in a manner similar to the NCC.
The copper:caeruloplasmin ratio does not have negative values for samples and overcomes the need for gender and age reference interval differences. Further evaluation using specimens from patients with a spectrum of metabolic copper problems is required to fully validate this concept. The similarity of our data to that of Beetham's, ${ }^{14}$ the coincidence of calculated and theoretical means and the fact that the results for patients with Wilson's disease with the lowest ratio would be abnormal using our reference interval is reassuring. The copper:caeruloplasmin ratio may be another useful tool in the diagnosis and investigation of copper metabolism disorders.

\section{Authors' affiliations}

Patrick J Twomey, Department of Clinical Biochemistry, The Ipswich Hospital, Ipswich, UK

Adie Viljoen, Department of Clinical Biochemistry, The Lister Hospital, Stevenage, UK

Ivan M House, The Medical Toxicology Unit Laboratory, Guy's \& St

Thomas' Hospital Trust, London, UK

Timothy M Reynolds, Department of Chemical Pathology, Queen's

Hospital, Burton-on-Trent, UK

Anthony S Wierzbicki, Department of Chemical Pathology, St Thomas'

Hospital, London, UK

Competing interests: None declared.

Correspondence to: Dr P J Twomey, The Ipswich Hospital, Heath Road, Ipswich IP4 5PD, UK; patrick.twomey@ipswichhospital.nhs.uk

Accepted 3 August 2006

\section{REFERENCES}

1 Anonymous. Wilson disease. OMIM 277900. On-line Mendelian Inheritance in Man 2005 May 7 (cited 2005). http://ncbi.nlm.nih.gov/omim (accesssed 24 Feb 2007).

2 Ferenci P. Review article: diagnosis and current therapy of Wilson's disease. Aliment Pharmacol Ther 2004; 19:157-65

3 Anonymous. Menke's disease. OMIM 309400. On-line Mendelian Inheritance in Man 2005 (cited 2005). http://ncbi.nlm.nih.gov/omim (accessed 24 Feb 2007).

4 Wierzbicki AS, Patel N, Evans K, et al. Copper-64 metabolism in two patients with non-Wilsonian movement disorders and copper deficiency. J Neurol Sci 1993; 1 19:85-90

5 Ito $\mathrm{S}$, Fujita $\mathrm{H}$, Narita $\mathrm{T}$, et al. Urinary copper excretion in type 2 diabetic patients with nephropathy. Nephron 2001;88:307-12.

6 Rowin J, Lewis SL. Copper deficiency myeloneuropathy and pancytopenia secondary to overuse of zinc supplementation. I Neurol Neurosurg Psychiatry 2005;76:750-1.

7 Shenkin A, Baines M, Fell GS, et al. Vitamins and trace elements. In: Burtis CA Ashwood ER, Bruns DE, eds. Tietz textbook of clinical chemistry and molecular diagnostics. 4th edn. St Louis, MO: Elsevier Saunders, 2006:1075-164.

8 Johnson PE, Milne DB, Lykken GI. Effects of age and sex on copper absorption biological half-life, and status in humans. Am J Clin Nutr 1992;56:917-25.

9 Walshe JM. Wilson's disease: the importance of measuring serum caeruloplasmin non-immunologically. Ann Clin Biochem 2003:40(P+ 2):115-21.

10 Holmberg CG, Laurell CB. Investigations in serum copper: (II). Isolation of the copper-containing protein and the description of some of its properties. Acta Chem Scand 1948;2:550-6.

11 Gaffney D, Fell GS, O'Reilly DS. ACP Best Practice No 163. Wilson's disease: acute and presymptomatic laboratory diagnosis and monitoring. J Clin Pathol 2000;53:807-12

12 Twomey PJ, Viljoen A, House IM, et al. Relationship between serum copper, ceruloplasmin, and non-ceruloplasmin-bound copper in routine clinical practice. Clin Chem 2005:51:1558-9.

13 Twomey PJ, Viljoen A, House IM, et al. Adjusting copper concentrations for caeruloplasmin levels. J Clin Pathol 2006;59:867-9.

14 Beetham R. Use of a serum copper to caeruloplasmin ratio to highlight relative copper excess in Wilson's disease. Ann Clin Biochem 2006;43(Suppl 1):53.

15 Beetham R, White $P$, Riches $P$, et al. Use of CRM 470/RPPHS has not achieved true consensus for ceruloplasmin measurement. Clin Chem 2002;48:2293-4. 